\begin{tabular}{|l|lll|}
\hline & Journal : Small 10526 & Dispatch : 8-10-2007 & Pages : 13 \\
& Article No. : 9124 & $\square$ LE & $\square$ TYPESET \\
MS Code : BICO618 & $\checkmark \mathrm{CP}$ & $\checkmark$ DISK \\
\hline
\end{tabular}

\title{
3 Harmonia axyridis in Great Britain: analysis of the 4 spread and distribution of a non-native coccinellid
}

\author{
5 Peter Michael James Brown - Helen E. Roy • Peter Rothery • David B. Roy • \\ 6 Remy L. Ware • Michael E. N. Majerus
}

7 Received: 30 July $2007 /$ Accepted: 4 October 2007

8 (C) International Organization for Biological Control (IOBC) 2007

9 Abstract Harmonia axyridis (Pallas) (Coleoptera: Coccinellidae) is native to Asia, and was widely introduced as a biocontrol agent of aphids and coccids in Europe and North America. In Europe $H$. axyridis is considered to be an invasive alien species. Although not known to have been deliberately introduced to Great Britain, it was first recorded there in 2004, in south-east England. Harmonia axyridis arrived in Great Britain by various means, primarily from mainland Europe, but also from Canada. Extensive national and local media coverage, and a dedicated website (http://www.harlequin-survey.org), facilitated public involvement in recording $H$. axyridis in Great Britain; in excess of 4,000 verified records of the species were received between 2004 and 2006. Through detailed mapping, the objective of our study was to quantify and analyse the spread of $H$. axyridis in its early stages of invasion in Great Britain. Our data shows that between 2004 and 2006, the

Type of article: Original research paper for the special edition "From biological control to invasion: the ladybird Harmonia axyridis as a model species".

P. M. J. Brown $(\varangle)$ · H. E. Roy · P. Rothery · D. B. Roy

Biological Records Centre, NERC Centre for Ecology and Hydrology - Monks Wood, Abbots Ripton,

e-mail: pmb@ceh.ac.uk

P. Rothery

A9 e-mail: pro@wpo.nerc.ac.uk

A10

\section{B. Roy}

e-mail: dbr@ceh.ac.uk

\section{A13 P. M. J. Brown - H. E. Roy}

A14 e-mail: hele@ceh.ac.uk

R. L. Ware M. E. N. Majerus 


\begin{tabular}{|l|lll|}
\hline & Journal : Small 10526 & Dispatch : 8-10-2007 & Pages : 13 \\
Article No. : 9124 & $\square$ LE & $\square$ TYPESET \\
MS Code : BICO618 & $\checkmark \mathrm{CP}$ & $\checkmark$ DISK \\
\hline
\end{tabular}

P. M. J. Brown et al.

species spread north through Great Britain at the rate of $58 \mathrm{~km} \mathrm{year}^{-1}$ and west at the rate of $144.5 \mathrm{~km} \mathrm{year}^{-1}$. In England H. axyridis spread north to Yorkshire and west to Cornwall by the end of 2006, and also reached Wales. Recorded occurrence (of one or more H. axyridis individuals at larval, pupal and/or adult stage) in $10 \mathrm{~km}$ squares in Great Britain was: 2004-51; 2005-149; 2006-447. Records of juvenile $H$. axyridis extend through most of the recorded British range of the species, and we present evidence of bi-voltinism in the population in 2006.

Keywords Alien species - Biological control · Coccinellidae - Harlequin ladybird · Harmonia axyridis $\cdot$ Invasive species $\cdot$ Non-native species

\section{Introduction}

The recording of biological events in Great Britain has a long tradition; detailed recording of many taxa has been carried out since the nineteenth century (Harding 1990). Biological records for Britain and Ireland are integrated and distributed through the National Biodiversity Network (NBN) gateway (http://www.searchnbn.net), an interactive mapping website holding in excess of 27 million records for over 8,500 species. The biological recording infrastructure in Great Britain provides an effective tool for monitoring species undergoing rapid range expansions. Analysis of long-term datasets showed that various taxa (e.g. dragonflies, butterflies, spiders and fish), are moving northwards in Great Britain in response to climate change (Hickling et al. 2006). Invasive species are regarded as one of the most serious threats to biodiversity (Glowka et al. 1994). The monitoring of biological invasions is vital, in order to understand the population dynamics, habitat tolerance and impact on native taxa, of the invading species. In Great Britain, monitoring projects for invasive insects include the horse chestnut leafminer Cameraria ohridella (Deschka and Dimic) (http://www.forestresearch.gov.uk/leafminer), and the rosemary beetle Chrysolina americana (L.) (http://www.rhs.org.uk/research/projects/rosemary_beetle.asp).

The harlequin ladybird or multicolored Asian lady beetle, Harmonia axyridis (Pallas) (Coleoptera: Coccinellidae), is native to Asia (e.g. Dobzhansky 1933; Kuznetsov 1997) and was introduced to North America and Europe to control pest aphid and coccid species on a range of crops (e.g. Adriaens et al. 2003; Koch 2003). It established in North America in 1988 (Chapin and Brou 1991), spread very rapidly (Koch 2003), and became the dominant coccinellid in many areas (Colunga-Garcia and Gage 1998; Smith et al. 1996; Tedders and Schaefer 1994). In mainland Europe, H. axyridis was first marketed as a biocontrol agent in 1995 (Coutanceau 2006), established in the late 1990s and expanded its range rapidly, especially from 2002 (Brown et al. submitted). It is not known to have been deliberately introduced to Great Britain, but arrived by various means, including flight and on produce from mainland Europe and in packing cases from Canada (Majerus et al. 2006a; Roy et al. 2005). There is no doubt that $H$. axyridis is an effective aphid predator, and its presence may be welcomed by some. However, there is concern in Europe about the rapid increase in distribution and abundance of $H$. axyridis, and its impact on non-target species (Adriaens et al. 2003; Majerus et al. 2006b; Roy et al. 2006). Although most biocontrol companies have stopped selling $H$. axyridis in Europe, a non-flying variety is still available from Biotop (http://www.biotop.fr).

Harmonia axyridis has the potential to contribute to biotic homogenization (McKinney and Lockwood 1999) and to negatively impact on up to 1,000 species in Great Britain (Majerus in press). These are primarily insects (including non-target Homoptera, 


\begin{tabular}{|l|lll|}
\hline & Journal : Small 10526 & Dispatch : 8-10-2007 & Pages : 13 \\
& Article No. : 9124 & $\square$ LE & $\square$ TYPESET \\
MS Code : BICO618 & $\checkmark$ CP & $\checkmark$ DISK \\
\hline
\end{tabular}

Spread of Harmonia axyridis in Great Britain

65

66

67

68

69

70

71

72

73

74

75

76

77

78

79

80

81

alternative prey, members of aphidophagous and coccidophagous guilds) and parasites, parasitoids, pathogens and symbionts of theses species (Majerus, in press). In the USA, H. axyridis has been declared a potential pest of fruit production and processing, as the species sometimes feeds on the juices of ripe fruits, such as apples, pears and grapes, in autumn (Koch 2003). Harmonia axyridis may become seriously pestilent to the native fauna of Great Britain (Majerus et al. 2006b). This pest status may extend directly to humans, as $H$. axyridis tends to form very large overwintering aggregations of thousands of individuals, often on or in buildings (Adriaens et al. 2003; Kidd et al. 1995). Some such aggregations were observed in England in 2006 (Brown and Roy 2007).

Uniquely, the early detection of $\mathrm{H}$. axyridis in Britain presented the opportunity to study the spread of an invasive animal from the year of its arrival (Majerus et al. 2006b). There is no evidence to suggest that $H$. axyridis was established in Great Britain before 2004 and circumstantial evidence that argues against its presence prior to that year (Majerus and Roy 2005). Through detailed mapping of adult and juvenile stages, the objective of our study was to quantify and analyse the spread of $H$. axyridis in its early stages of invasion in Great Britain. A further objective was to investigate the voltinism of $H$. axyridis in Great Britain, to determine whether there was evidence of multiple generations per year.

\section{Material and methods}

Data collection

The spread of $H$. axyridis was monitored by utilising the extensive biological recording community in Great Britain, coupled with engagement of the general public. Recent advances in technology, and high levels of public access to the internet and digital photography, enabled a web-based biological survey to be set up. The Harlequin Ladybird Survey (http://www.harlequin-survey.org) was one of the first online surveys of its kind in Great Britain. It was launched in March 2005 in response to the first report of H. axyridis in Great Britain, in September 2004 (Majerus 2004). The survey benefited from high levels of media interest, including the front page of The Times on 15 March 2005. Members of the British public showed great willingness to look for $H$. axyridis, and to register their sightings with the survey.

The dataset presented here comprises 4,117 species records of $H$. axyridis in Great Britain between 2004 and 2006. Each record represents a verified sighting of $H$. axyridis on a given date, and comprises one or more individual ladybirds observed from one or more life stages (larva, pupa and adult; records of eggs were not included). $76 \%$ of these records were received from members of the British public by post, or entered online at the Harlequin Ladybird Survey website or UK Ladybird Survey website (http://www. ladybird-survey.org); the latter was set up to encourage the recording of native ladybirds. Verification of the records was made by the authors after receipt of either a specimen or photograph. Most photographs were received as digital images attached to emails. The remaining $24 \%$ of records were received from coleopterists and other naturalists, and in particular from the London and Essex Ladybird Survey. Such records were not verified by the authors but are regarded as accurate and so have been included in the dataset. A further 4,316 online records were received that remain unverified (i.e. no photograph or specimen was sent), or were verified as another species, and so are not included in the analyses. Verified records were regularly uploaded to the database of the National 


\begin{tabular}{|l|lll|}
\hline & Journal : Small 10526 & Dispatch : 8-10-2007 & Pages : 13 \\
& Article No. : 9124 & $\square$ LE & $\square$ TYPESET \\
MS Code : BICO618 & $\checkmark \mathrm{CP}$ & $\checkmark$ DISK \\
\hline
\end{tabular}

P. M. J. Brown et al.

109 Biodiversity Network. There they could be viewed via online maps, which helped to 110 encourage further recording.

111 Each species record includes the following data: recorder name; location of sighting 112 (the grid reference of the Ordinance Survey British national grid reference system); 113 locality/site name (not included for all records); date of sighting; life stage observed (larva, pupa, adult); number of each life stage observed (assumed to equal 1, if not specified); and determiner name. Additional optional attributes include the number of each colour form of any adults observed (included for $82 \%$ of records), and supplementary comments, including habitat and/or behavioural information.

Three main colour forms of adult $H$. axyridis have been found in Great Britain: succinea, f. spectabilis and f. conspicua. The succinea complex has been divided into 120 many subforms (e.g. siccoma-0 spots; frigida-6 spots; novemdecimsignata-19 spots) (Dobzhansky 1933), but is treated as a single form here. Thus f. succinea has elytra with a ground colour of yellow, orange, or red, and 0-21 black spots, which may or may not be fused. F. spectabilis has black elytra with four yellow, orange, or red spots or other shaped markings, which sometimes contain a central black spot. F. conspicua is as f. spectabilis, but with only two spots.

The spatial resolution of the records is variable, and while approximately $20 \%$ include a grid reference, enabling resolution to $100 \mathrm{~m}$, the other approximate $80 \%$ of records were derived at $1 \mathrm{~km}$ resolution from a UK postal code (UK Government Data Standards Catalogue, http://www.govtalk.gov.uk/gdsc/html/frames/PostCode.htm). The option on the online recording form to enter the location via a UK postal code was provided to make the entry of records easier for members of the public unfamiliar with the grid reference system. Whilst the resolution is thus reduced for these records, the reduction in user error (e.g. the problem of grid reference eastings and northings being transposed), is an advantage (Majerus et al. 1990). The postal code method was applicable for sightings of $H$. axyridis made within $200 \mathrm{~m}$ of a specified postal code, so could not be used for a minority of records where the ladybird was seen in a semi-natural habitat.

Variability in recording effort (both temporally and spatially) is clearly an issue when analysing a dataset of the kind presented here. Other factors being equal, more records will come from areas with a higher density of recorders. Across Great Britain there were a number of particularly active local groups or individuals, which contributed hotspots of recorder activity, potentially biasing the results for certain areas, e.g. London, because of the high activity of the London and Essex Ladybird Survey. The Harlequin Ladybird Survey benefited from a high profile and enjoyed frequent local and national media attention, thus potentially increasing the volume of records received at certain times. To minimise these effects, the data have mostly been analysed in terms of the presence of $H$. axyridis in $10 \mathrm{~km}$ squares ( $1 \mathrm{~km}$ squares for juveniles) by year. Thus, whether the species was recorded just once or many times in any given square in a year, is not reflected in the analyses. To many recorders, juvenile stages were less noticeable and more difficult to identify than the adult stage, thus generally limiting the recording of juveniles.

The possibility of a reporting bias towards sightings early in the season also existed (i.e. some recorders may have reported their first sighting of $H$. axyridis, but not subsequent sightings). In order to minimise this effect, the importance of recording multiple sightings was stressed to recorders. The peaks in record numbers observed late in each year also suggest that any effect of this potential bias was minor. 


\begin{tabular}{|l|lll|}
\hline & Journal : Small 10526 & Dispatch : 8-10-2007 & Pages : 13 \\
Article No. : 9124 & $\square$ LE & $\square$ TYPESET \\
MS Code : BICO618 & $\checkmark \mathrm{CP}$ & $\checkmark$ DISK \\
\hline
\end{tabular}

Spread of Harmonia axyridis in Great Britain

Rate of spread

157 The location of the northern range margin of $H$. axyridis in Great Britain was measured by calculating the mean northing of the ten most northerly $10 \mathrm{~km}$ squares occupied each year (Hickling et al. 2006). The location of the range margins in the westerly and north-westerly directions were calculated each year using the same method. There is a very strong assumption that $H$. axyridis colonised Great Britain primarily from the coastal regions of northern France, Belgium and the Netherlands (Majerus et al. 2006a), hence the inclusion of the north-westerly direction.

Seasonal pattern

165

The seasonal pattern of $H$. axyridis sightings in 2005 and 2006 were examined. Harmonia axyridis was first recorded in Great Britain in July 2004, so that year was excluded from the analyses because of incomplete data. The data are weekly counts of the occurrence of $H$. axyridis in grid squares. For adult $H$. axyridis $10 \mathrm{~km}$ squares were used, but for juveniles (i.e. larvae and pupae), because of a lower number of records, $1 \mathrm{~km}$ squares were used.

Seasonal patterns were analysed using a Generalized Additive Model (GAM) in which the counts varied randomly about a smooth trend described by a cubic smoothing spline (Green and Silverman 1994). The degrees of freedom for the fitted GAM were determined using cross-validation (leaving out each data point in turn) and minimising the crossvalidation Poisson deviance. A GAM was fitted separately to data from 2005 and 2006 to describe the seasonal pattern of observations in each year. The number of sightings was generally higher throughout 2006 compared to 2005, but the GAM curves allow comparison of the shape of the seasonal pattern each year. The null hypothesis of equality of shape in 2005 and 2006 implies that curves differ by some constant factor, i.e. parallel on a $\log$ scale. The alternative hypothesis allows different curves in each year. The test-statistic is $F=\left\{\left(D_{\text {null }}-D_{\text {alt }}\right) /\left(d f_{\text {null }}-d f_{\text {alt }}\right)\right\} / D_{\text {alt }} / d f_{\text {alt }}$, where $D$ denotes the residual deviance and $d f$ is the corresponding degrees of freedom. On the null hypothesis, the statistic follows an

$183 F$ distribution with $\left(d f_{\text {null }}-d f_{\text {alt }}\right)$ and $d f_{\text {alt }}$ degrees of freedom. The analysis was performed using the statistical package Genstat 6 (Payne et al. 2002).

\section{Results}

Abundance and rate of spread

Harmonia axyridis has spread rapidly in Great Britain (Fig. 1a). Recorded occurrence (of 188 one or more $H$. axyridis individuals at larval, pupal and/or adult stage) in $10 \mathrm{~km}$ squares in Great Britain was: 51 in 2004; 149 in 2005; 447 in 2006; representing a 2.9-fold increase from 2004 to 2005 and a 3.0-fold increase from 2005 to 2006 . There was a 2.7 -fold increase in the number of adult $H$. axyridis records, and a 2.9-fold increase in the number of individual adults recorded, from 2005 to 2006 (Table 1).

The number of $10 \mathrm{~km}$ squares with records of juvenile $H$. axyridis increased from 8 in 2004, to 51 in 2005, and 75 in 2006 (Fig. 1b). In 2004, evidence of H. axyridis breeding was restricted to London and East Anglia, with juveniles recorded in a wider range of counties in 2005 (notably Kent and Derbyshire). Further evidence of breeding was 


\begin{tabular}{|l|lll|}
\hline & Journal : Small 10526 & Dispatch : 8-10-2007 & Pages : 13 \\
& Article No. : 9124 & $\square$ LE & $\square$ TYPESET \\
MS Code : BICO618 & $\checkmark \mathrm{CP}$ & $\checkmark$ DISK \\
\hline
\end{tabular}

P. M. J. Brown et al.

(a)

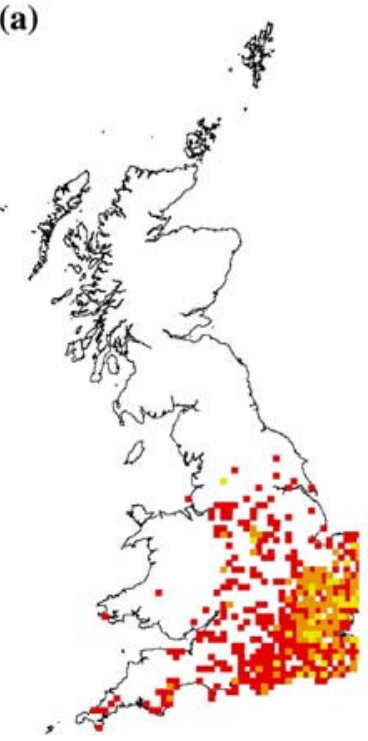

(b)
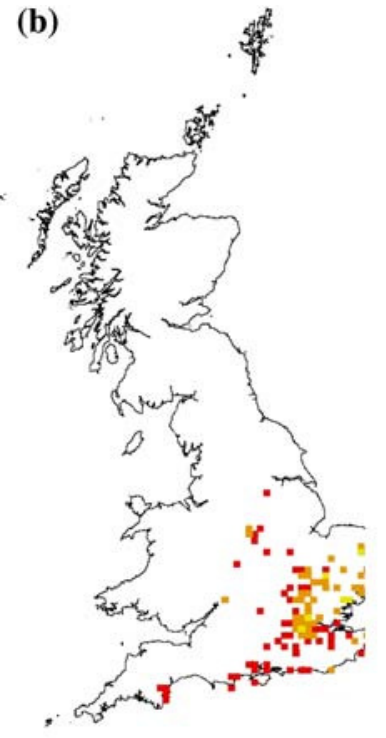

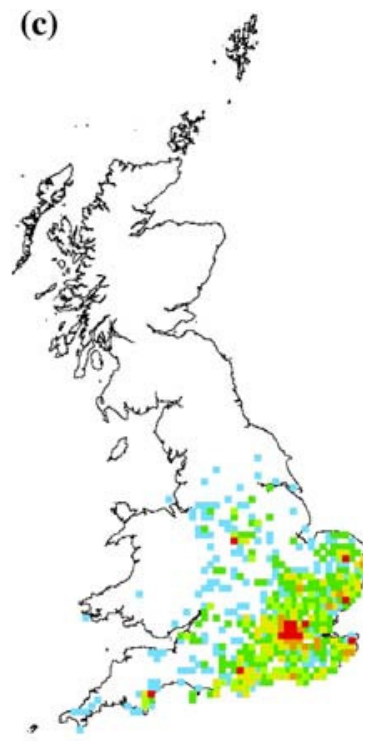

Fig. 1 Harmonia axyridis occurrence in $10 \mathrm{~km}$ squares in Great Britain from 2004 to 2006. For (a) and (b), where a square has been recorded in more than one year, occurrence in the earliest year is shown (yellow = 2004; orange $=2005$; red = 2006). (a) Adults and juveniles; (b) Juveniles only; (c) Density of records of adults and juveniles; $($ red $=50+$ records per square; orange $=20-49$; yellow $=10-19$; pale green $=6-9 ;$ dark green $=2-5 ;$ blue $=1$ )

recorded across south-east England, and west as far as Devon, and north as far as Yorkshire, in 2006 (Fig. 1b).

Northerly spread (Fig. 2a) distances per year were: $19 \mathrm{~km}$ between 2004 and 2005; $20097 \mathrm{~km}$ between 2005 and 2006; mean $-58 \mathrm{~km}$ year ${ }^{-1}$. Westerly spread (Fig. 2b) distances 201 per year were: $107 \mathrm{~km}$ between 2004 and 2005; $182 \mathrm{~km}$ between 2005 and 2006; mean$202144.5 \mathrm{~km} \mathrm{year}^{-1}$. North-westerly spread (Fig. 2c) distances per year were: $81.2 \mathrm{~km}$ 203 between 2004 and 2005; $107.5 \mathrm{~km}$ between 2005 and 2006; mean-94.3 $\mathrm{km}_{\text {year }}{ }^{-1}$.

Table 1 Summary of Harlequin Ladybird Survey data from Great Britain (Note-records of large aggregations without a specific number of ladybirds recorded have been excluded)

\begin{tabular}{lccccc}
\hline Life stage & Year & $\begin{array}{l}\text { No. verified } \\
\text { records }\end{array}$ & $\begin{array}{l}\text { Total no. H. axyridis } \\
\text { recorded }\end{array}$ & $\begin{array}{l}\text { Mean no. H. axyridis } \\
\text { per record }\end{array}$ & $\begin{array}{l}\text { Maximum no. } \\
\text { H. axyridis recorded }\end{array}$ \\
\hline Larva & 2004 & 13 & 54 & 4.2 & 10 \\
& 2005 & 182 & 1,817 & 10.0 & 266 \\
& 2006 & 145 & 1,410 & 9.7 & 200 \\
\multirow{4}{*}{ Pupa } & 2004 & 5 & 27 & 5.4 & 10 \\
& 2005 & 81 & 1,194 & 14.7 & 227 \\
& 2006 & 23 & 231 & 10.0 & 53 \\
\multirow{4}{*}{ Adult } & 2004 & 119 & 344 & 2.9 & 25 \\
& 2005 & 1,045 & 6,180 & 5.9 & 399 \\
& 2006 & 2,825 & 17,641 & 6.2 & 689 \\
\hline
\end{tabular}




\begin{tabular}{|l|lll|}
\hline & Journal : Small 10526 & Dispatch : 8-10-2007 & Pages : 13 \\
& Article No. : 9124 & $\square$ LE & $\square$ TYPESET \\
MS Code : BICO618 & $\checkmark \mathrm{CP}$ & $\checkmark$ DISK \\
\hline
\end{tabular}

Spread of Harmonia axyridis in Great Britain

(a)

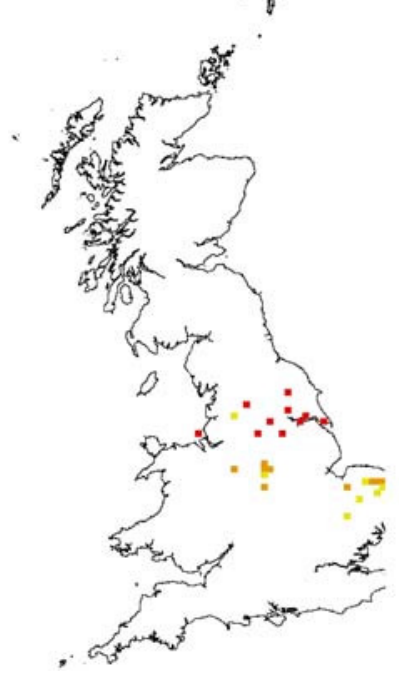

(b)

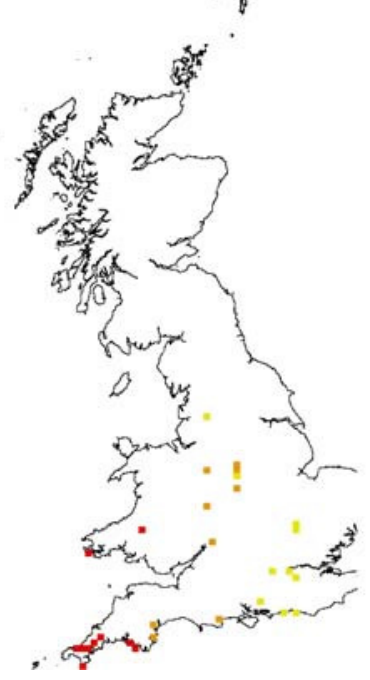

(c)

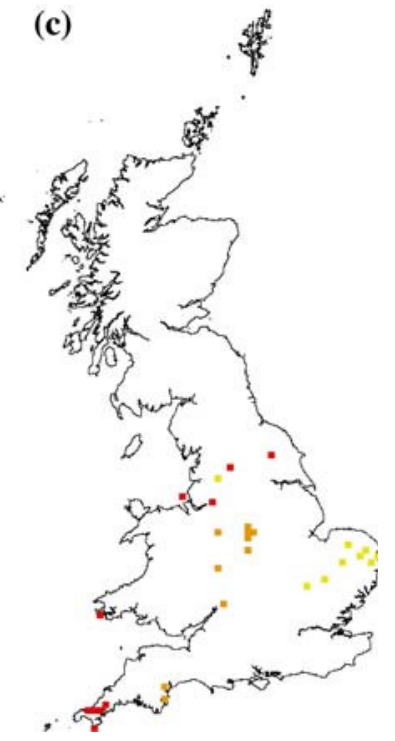

Fig. 2 Range margin of $H$. axyridis in $10 \mathrm{~km}$ squares in Great Britain from 2004 to 2006. Where a square has been recorded in more than one year, occurrence in the earliest year is shown (yellow $=2004$; orange $=2005$; red $=2006$ ). $($ a) Ten most northerly squares; (b) Ten most westerly squares; (c) Ten most north-westerly squares

212 Seasonal pattern

\section{Adults}

214 The seasonal patterns of spread of adult $H$. axyridis in 2005 and 2006 were significantly 215 different $\left(F_{12,78}=2.52, P=0.007\right)$. The main difference in the smoothed curves was 216 during the period 23-34 weeks, where there was a seasonal peak observed in 2006, which 217 was not observed in 2005 (Fig. 3a and b).

Juveniles

219 The seasonal patterns of spread of juvenile $H$. axyridis in 2005 and 2006 were significantly 220 different $\left(F_{6,89}=3.57, P=<0.001\right)$. The main difference is the extra peak around week 25 


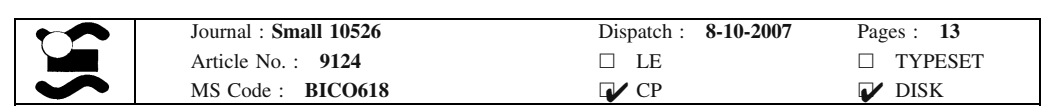

P. M. J. Brown et al.

Fig. 3 Adult H. axyridis occurrence in $10 \mathrm{~km}$ squares in Great Britain with fitted GAMs and degrees of freedom (df). (a) $2005(\mathrm{df}=12) ;(\mathbf{b}) 2006$ $(\mathrm{df}=13)$
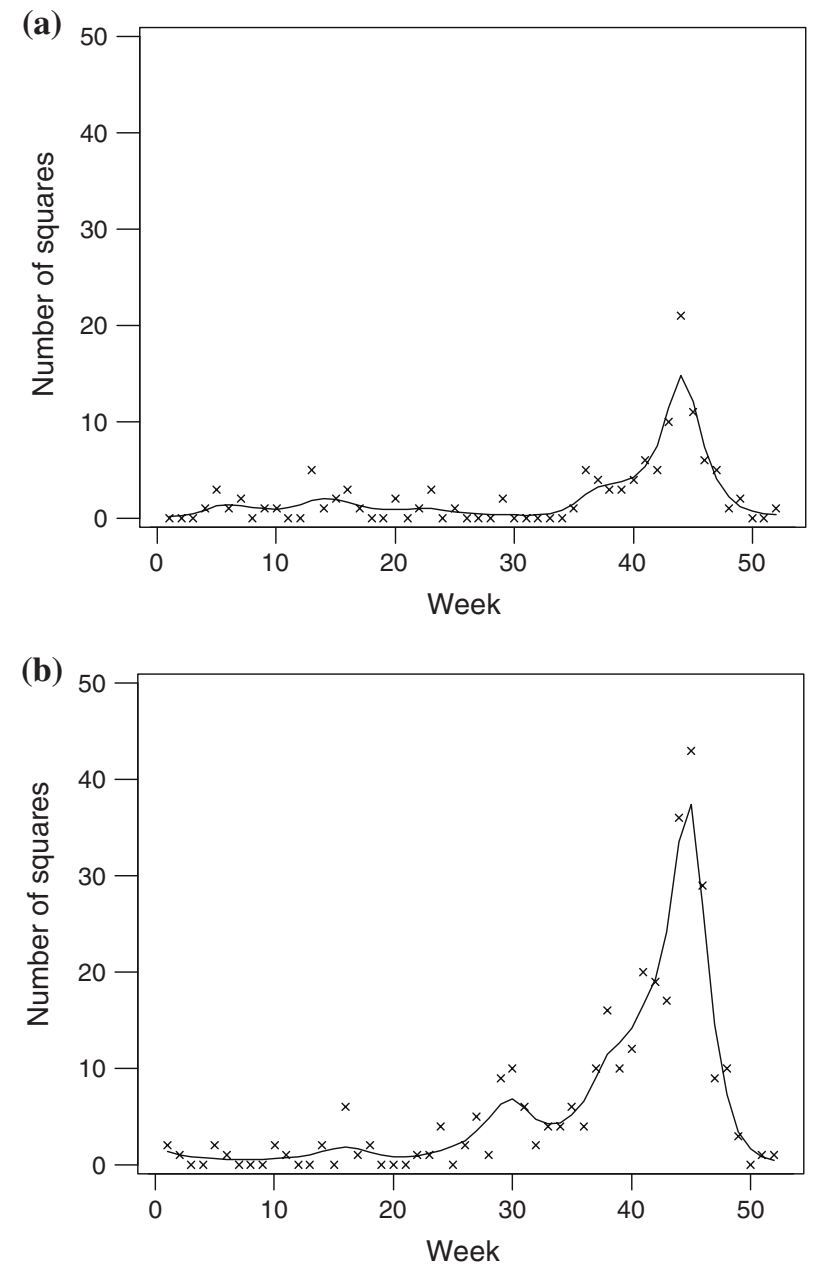

221 in 2006, and the earlier date of the autumn peak in 2006. For the fitted GAMs, the main 222 peaks occur at week 44 (2005) and week 40 (2006) (Fig. 4a and b).

\section{Discussion}

\section{Rate of spread}

225 The rate of spread and increase in abundance of $H$. axyridis in Great Britain has been 226 dramatic. Westerly spread was faster than northerly spread by a factor of approximately 227 2.5, and this may partly be explained by the likelihood of repeated recruitment of 228 H. axyridis from mainland Europe. Indeed, in 2006, eight of the ten most westerly $10 \mathrm{~km}$ 229 squares occupied were in the extreme south-west of England and close to the coast, 230 possibly representing new recruits from abroad, rather than spread from the existing British 231 range. This factor is presumed not to apply to the most northerly squares occupied, because 


\begin{tabular}{|l|lll|}
\hline & Journal : Small 10526 & Dispatch : 8-10-2007 & Pages : 13 \\
& Article No. : 9124 & $\square$ LE & $\square$ TYPESET \\
MS Code : BICO618 & $\checkmark \mathrm{CP}$ & $\checkmark$ DISK \\
\hline
\end{tabular}

Spread of Harmonia axyridis in Great Britain

Fig. 4 Juvenile $H$. axyridis occurrence in $1 \mathrm{~km}$ squares in Great Britain with fitted GAMs and degrees of freedom (df). (a) $2005(\mathrm{df}=6) ;($ b) $2006(\mathrm{df}=6)$
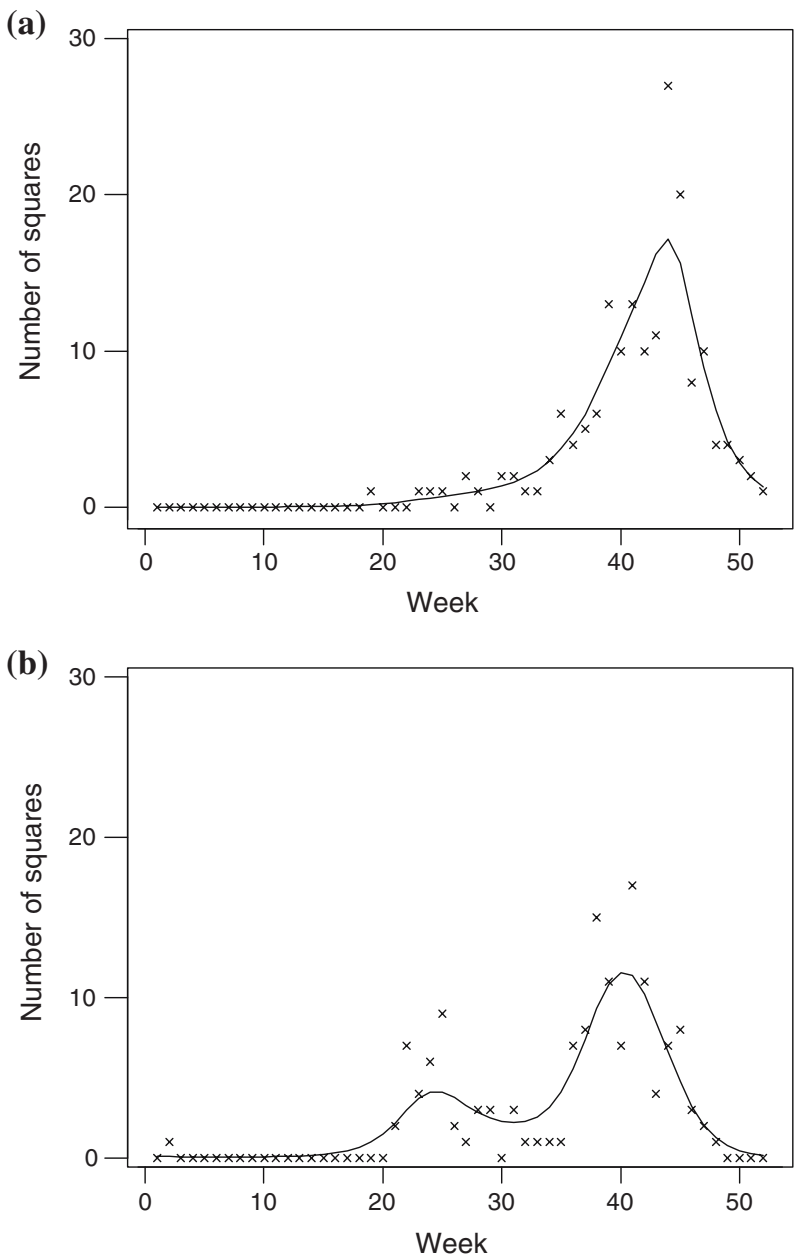

of their greater distance from mainland Europe and, in most cases, their lack of proximity 233 to the British coast. Ecological factors such as climate and habitat type may also have 234 influenced the faster westerly spread. In late October and early November 2006 there was an influx of reports of large aggregations of $H$. axyridis adults, mainly at locations close to the south coast of England. Aggregations of hundreds and in a few cases, thousands, of H. axyridis were observed (Brown and Roy 2007). Whether these large aggregations represented new recruits from mainland Europe has yet to be determined.

The most closely related species to $H$. axyridis in Great Britain is Harmonia quadripunctata (Pontoppidan). This species is also a relatively recent arrival to Britain, but is now regarded as a native species, having expanded its native range northwards within Europe, and is assumed to have reached Britain by natural means (Majerus and Kearns 1989; Majerus 1994). It is not considered invasive. Although $H$. quadripunctata is far more habitat-specific than H. axyridis, and the mechanisms of spread may not be the same, a comparison of the rate of spread of the two species is enlightening. Majerus and Kearns (1989) outline the spread of $H$. quadripunctata. It was first recorded in Great Britain in 


\begin{tabular}{|l|lll|}
\hline & Journal : Small 10526 & Dispatch : 8-10-2007 & Pages : 13 \\
& Article No. : 9124 & $\square$ LE & $\square$ TYPESET \\
MS Code : BICO618 & $\checkmark \mathrm{CP}$ & $\checkmark$ DISK \\
\hline
\end{tabular}

P. M. J. Brown et al.

West Suffolk (East Anglia) in 1937, and based on earliest records for each vice county, took fifty years to spread west as far as Devon, in south-west England. Our data show that H. axyridis took just two years to spread to Devon from a similar starting point in East Anglia.

In Great Britain, the northerly range expansion of some insect groups was calculated by Hickling et al. (2006), giving figures of up to $4.2 \mathrm{~km} \mathrm{year}^{-1}$ (over a 25 year period) for the most dispersive taxa (dragonflies); but these range expansions were for native species responding to climate change, rather than for invasive species. There is limited quantitative data on the spread of invasive insects in Europe. The spread of the horse chestnut leafminer C. ohridella in Germany in the late 1990s was modelled, and the rate of spread calculated to vary between $54 \mathrm{~km}_{\text {year }}{ }^{-1}$ and $330 \mathrm{~km} \mathrm{year}^{-1}$ (Gilbert et al. 2004), figures of the same order of magnitude as our calculations for H. axyridis in Britain. In eastern North America the rate of range expansion of $H$. axyridis was estimated at $442 \mathrm{~km} \mathrm{year}^{-1}$ (McCorquodale 1998). As it was probably confounded by many intentional releases at various locations (McCorquodale 1998), this very fast expansion is not a fair comparison with that observed in Great Britain. Expansion was thought to be slower in other parts of North America (Koch et al. 2006).

Abundance and mechanism of spread

Abundance of $H$. axyridis in Great Britain increased rapidly from 2004 to 2006, and this trend is predicted to continue. There is very strong demographic evidence that the spread of H. axyridis in Great Britain did not originate from a single immigration event, and that the species arrived at different locations at various times, and by various means. Apart from the spread (by flight) from continental Europe, some specimens of $H$. axyridis are known to have arrived in England on imported flowers from the Netherlands, and in packing cases from Canada (Majerus et al. 2006a). By 2004, H. axyridis had sufficient time to adapt to conditions in mainland Europe and was building-up in number and spreading fast. Crossing the English Channel to reach Great Britain was not a major step. It is a coincidence that specimens from Canada were found in Great Britain for the first time in the same year, and it is possible that it had arrived by similar mechanisms in earlier years, but failed to be noticed and failed to establish.

A separate population of $H$. axyridis was evident in Derby (central England) in 2004, which is thought to have originated from specimens arriving with produce to a supermarket in the city (W. Grange, personal communication). Derby was not the most northerly verified location of $H$. axyridis in 2004 (a single specimen was recorded in Lancashire, but with no evidence of subsequent establishment), but is the only place outside of the southeast with multiple verified records of $H$. axyridis in each of 2004, 2005 and 2006. Large numbers of $H$. axyridis (three records each of 50+ individuals) were recorded in Derby in 2005. The colour form profile of the Derby population almost totally lacked melanics in 2004 and 2005 (99.6\% f. succinea; $\mathrm{n}=495)$, in contrast to other parts of the country, where melanic specimens formed a significant proportion of the population (a mean of $20 \%$ melanic specimens were recorded in 2005). The clear difference in colour form profile strongly suggests a genetically distinct population, and further work is in progress to examine this.

The observed reduction in both the number of juvenile records, and mean number of juveniles per record, from 2005 to 2006, is not believed to reflect a true reduction in breeding activity. Rather, this is likely to be the effect of reduced recorder effort. In 


\begin{tabular}{|l|lll|}
\hline & Journal : Small 10526 & Dispatch : 8-10-2007 & Pages : 13 \\
Article No. : 9124 & $\square$ LE & $\square$ TYPESET \\
MS Code : BICO618 & $\checkmark$ CP & $\checkmark$ DISK \\
\hline
\end{tabular}

Spread of Harmonia axyridis in Great Britain

Evidence of bi-voltinism

304

305

306

307

308

309

310

311

312

313 activity. H. axyridis observed.

\section{Habitat use}

\section{Conclusion}

particular, recorders with the London and Essex Ladybird Survey worked diligently in 2005 to gather juvenile records, and provided $46 \%$ of all such records; this effort was reduced to $9 \%$ of the total in 2006. A $47 \%$ increase in the number of $10 \mathrm{~km}$ squares with juvenile records from 2005 to 2006 suggests that there was in fact an increase in breeding

Examples of invasive species in Great Britain exhibiting a 'boom-and-bust' population cycle are unusual, although this scenario did apply to the rhododendron lacebug Stephanitis rhododendri (Horvath) (Williamson 1996). The evidence from almost 20 years as an established introduced species in North America suggests that this will not apply to H. axyridis on either side of the Atlantic.

Some of the common and widespread coccinellid species in Britain, e.g. Coccinella septempunctata (L.), are limited by the requirement of a winter dormancy period before they can reproduce (Majerus 1994). Harmonia axyridis does not have this limit to population growth and may have several generations per year, five having been recorded in Asia (Wang 1986) and four in southern Europe (Katsoyannos et al. 1997). In the cool and damp maritime climate of Great Britain, we predict $H$. axyridis will achieve two, or possibly three, generations per year. There is evidence of a second generation in 2006 in the data presented here, with a summer peak (week 24) and an autumn peak (week 40), in juvenile records. Production of two generations would help to explain the very rapid spread of

The dataset reflects a somewhat urban distribution. Although some of this effect may be biased by higher recorder effort in urban areas, it is assumed to be the result of genuine habitat preference by $H$. axyridis. Lime trees, Tilia sp. and sycamore trees, Acer sp. were recorded as favoured habitats, and these trees are generally found in Britain in urban locations, such as parks, gardens, lining roads and churchyards. Whether $H$. axyridis will thrive in semi-natural habitats is a question that remains to be answered, and an important one in terms of the potential impact of the species on native coccinellids and other insects. Harmonia axyridis has been recorded in various semi-natural habitats in Great Britain, including reedbeds, and on planted and self-seeded Pinus sylvestris (L.) in East Anglia. Mature $P$. sylvestris is an important habitat for several native coccinellids, including Anatis ocellata (L.), Myzia oblongoguttata (L.) and Myrrha octodecimguttata (L.) (Majerus 1994). Evidence of the strength of intraguild predation by H. axyridis (Pell et al. submitted; Roy et al. in press; Ware and Majerus submitted; Ware et al. in press) deepens concern that the species will have a serious negative impact on native coccinellids.

We predict that the spread of $H$. axyridis in Great Britain will continue at a rapid pace, and that the species will become established in Scotland by the end of 2008. To determine the impact of $H$. axyridis on native species, monitoring of ladybird populations is required in 


\begin{tabular}{|l|llll|}
\hline & Journal : Small 10526 & Dispatch : $\mathbf{8 - 1 0 - 2 0 0 7}$ & Pages : $\mathbf{1 3}$ \\
& Article No. : $\mathbf{9 1 2 4}$ & $\square$ LE & $\square$ TYPESET \\
\hline
\end{tabular}

P. M. J. Brown et al.

semi-natural habitats and urban habitats, both of which can support high abundance and species richness. Quantitative research at appropriate spatial and temporal scales is essential, if we are to objectively assess the ecological impact of $H$. axyridis. Field studies need to focus on habitat use by this species and its interactions within the large guild of associated aphidophagous species. Harmonia axyridis has many traits that have ensured its status as a successful invasive alien species. The continued population expansion within and beyond its invaded range seems inevitable.

Acknowledgements We extend our thanks to all of the following, who have helped to make the Harlequin Ladybird Survey a success: the thousands of naturalists and members of the British public who have provided records; Department for Environment Food and Rural Affairs, National Biodiversity Network Trust, Joint Nature Conservation Committee, Natural Environment Research Council, University of Cambridge and Anglia Ruskin University for funding and support; Paul Mabbott and recorders from the London and Essex Ladybird Survey; Trevor James, Jim Munford and Andrew Brewer of the National Biodiversity Network Trust; Mark Hill, Cassie Hoyland and Henry Arnold of the Biological Records Centre; Ian Wright, Laura-Jane Michie, James Waters and Francis Rowland of University of Cambridge; Julian Doberski of Anglia Ruskin University; and finally Robert Frost and William Grange for records and valuable contributions.

\section{References}

Adriaens T, Branquart E, Maes D (2003) The multicoloured Asian ladybird Harmonia axyridis Pallas (Coleoptera: Coccinellidae), a threat for native aphid predators in Belgium? Belg J Zool 133:195-196 Brown PMJ, Roy HE (2007) The spread of the harlequin ladybird Harmonia axyridis in late 2006. Atropos 31:32-33

Brown PMJ, Adriaens T, Bathon H, Cuppen J, Goldarazena A, Hägg T, Kenis M, Klausnitzer BEM, Kovar I, Loomans AJM, Majerus MEN, Nedved O, Pedersen J, Rabitsch W, Roy HE, Ternois V, Zakharov IA, Roy DB Harmonia axyridis in Europe: spread and distribution of a non-native coccinellid. BioControl, submitted to BioControl SI

Chapin JB, Brou VA (1991) Harmonia axyridis (Pallas), the 3rd species of the genus to be found in the United States (Coleoptera, Coccinellidae). Proc Entomol Soc Wash 93:630-635

Colunga-Garcia M, Gage SH (1998) Arrival, establishment, and habitat use of the multicolored Asian lady beetle (Coleoptera: Coccinellidae) in a Michigan landscape. Environ Entomol 27:1574-1580

Coutanceau J-P (2006) Harmonia axyridis (Pallas, 1773): une coccinelle asiatique introduite, acclimatée et en extension en France. Bulletin de la Société entomologique de France 111:395-401

Dobzhansky T (1933) Geographical variation in ladybeetles. Am Nat 67:97-126

Gilbert M, Grégoire J-C, Freise JF, Heitland W (2004) Long-distance dispersal and human population density allow the prediction of invasive patterns in the horse chestnut leafminer Cameraria ohridella. J Anim Ecol 73:459-468

Glowka L, Burhenne-Guilmin F, Synge H, McNeely J, G'ndling L (1994) A guide to the convention on biological diversity (Environmental Policy and Law paper no. 30). International Union for the Conservation of Nature, Gland

Green P, Silverman BW (1994) Non-parametric regression and generalized additive models. Chapman and Hall, London

Harding PT (1990) National species distribution surveys. In: Goldsmith FB (ed) Monitoring for conservation and ecology. Chapman and Hall, London

Hickling R, Roy DB, Hill JK, Fox R, Thomas CD (2006) The distributions of a wide range of taxonomic groups are expanding polewards. Global Change Biology 12:450-455

Katsoyannos P, Kontodimas DC, Stathas GJ, Tsartsalis CT (1997) Establishment of Harmonia axyridis on citrus and some data on its phenology in Greece. Phytoparasitica 25:183-191

Kidd KA, Nalepa CA, Day ER, Waldvogel MG (1995) Distribution of Harmonia axyridis (Pallas) (Coleoptera, Coccinellidae) in North Carolina and Virginia. Proc Entomol Soc Wash 97:729-731

Koch RL (2003) The multicolored Asian lady beetle, Harmonia axyridis: a review of its biology, uses in biological control, and non-target impacts. J Insect Sci 3:1-16

Koch RL, Venette RC, Hutchison WD (2006) Invasions by Harmonia axyridis (Pallas) (Coleoptera: Coccinellidae) in the western hemisphere: implications for South America. Neotrop Entomol 35:421-434 


\begin{tabular}{|l|lll|}
\hline & Journal : Small 10526 & Dispatch : 8-10-2007 & Pages : 13 \\
Article No. : 9124 & $\square$ LE & $\square$ TYPESET \\
MS Code : BICO618 & $\checkmark \mathrm{CP}$ & $\checkmark$ DISK \\
\hline
\end{tabular}

Spread of Harmonia axyridis in Great Britain

Kuznetsov VN (1997) Lady beetles of Russian far east. The Sandhill Crane Press, Gainesville

Majerus MEN (1994) Ladybirds. No. 81, New Naturalist series. HarperCollins, London

Majerus MEN (2004) The ladybird has landed. University of Cambridge press release, 4 October 2004

Majerus MEN Generalist and specialist ladybirds. British Naturalists' Association, in press

Majerus MEN, Kearns P (1989) Ladybirds. Richmond Publishing, Slough

Majerus MEN, Roy HE (2005) Scientific opportunities presented by the arrival of the harlequin ladybird, Harmonia axyridis, in Britain. Antenna 29:196-208

Majerus MEN, Forge H, Walker L (1990) The geographical distributions of ladybirds in Britain (19841989). Br J Entomol Nat Hist 3:153-166

Majerus MEN, Mabbott P, Rowland F, Roy HE (2006a) The harlequin ladybird, Harmonia axyridis, arrives in Britain. Entom Mon Mag 142:87-92

Majerus M, Strawson V, Roy H (2006b) The potential impacts of the arrival of the harlequin ladybird, Harmonia axyridis (Pallas) (Coleoptera: Coccinellidae), in Britain. Ecol Entomol 31:207-215

McCorquodale DB (1998) Adventive lady beetles (Coleoptera: Coccinellidae) in eastern Nova Scotia, Canada. Entomol News 109:15-20

McKinney ML, Lockwood JL (1999) Biotic homogenization: a few winners replacing many losers in the next mass extinction. Trends Ecol Evol 14:450-453

Payne RW, members of the Genstat 6 Committee (2002) Genstat 6 release 1 reference manual. Oxford University Press, Oxford

Pell JK, Baverstock J, Roy HE, Majerus MEN, Ware RL Intraguild predation of native aphidophages by Harmonia axyridis; a review and future perspectives. BioControl, submitted to BioControl SI

Roy HE, Rowland F, Brown PMJ, Majerus MEN (2005) Ecology of the harlequin ladybird: a new invasive species. Br Wildl 16:403-407

Roy HE, Brown P, Majerus MEN (2006) Harmonia axyridis: a successful biocontrol agent or an invasive threat? In: Eilenberg J, Hokkanen H (eds) An ecological and societal approach to biological control. Kluwer Academic Publishers, Dordrecht

Roy HE, Baverstock J, Ware RL, Clark SJ, Majerus MEN, Baverstock KE, Pell JK Intraguild predation of the aphid pathogenic fungus Pandora neoaphidis by the invasive coccinellid Harmonia axyridis. Ecological Entomology, in press

Smith WM, Arnold DC, Eikenbary RD, Rice NR, Shiferaw A, Cheary BS, Carroll BL (1996) Influence of ground cover on beneficial arthropods in pecan. Biol Control 6:164-176

Tedders WL, Schaefer PW (1994) Release and establishment of Harmonia axyridis (Coleoptera, Coccinellidae) in the southeastern United States. Entomol News 105:228-243

Wang LY (1986) Mass rearing and utilization in biological control of the lady beetle Leis axyridis (Pallas). Acta Entomologica Sinica 29:104

Ware RL, Majerus MEN Intraguild predation of immature stages of British and Japanese coccinellids by the invasive ladybird Harmonia axyridis. BioControl, submitted to BioControl SI

Ware RL, Evans N, O'Farrell K, Majerus MEN, Malpas L, Michie LJ Intraguild predation by the invasive ladybird Harmonia axyridis: 1: British and Japanese coccinellid eggs. Neobiota, in press

Williamson M (1996) Biological invasions. Chapman and Hall, London 